\title{
MIKROKAPCSOLÓK TÖNKREMENETELI EREDMÉNYEINEK ELEMZÉSE
}

\author{
Sipkás Vivien \\ PhD hallgató, Miskolci Egyetem Gép- Terméktervezési Intézet \\ 3515 Miskolc,Miskolc-Egyetemváros, e-mail: machsv@uni-miskolc.hu \\ Vadászné Bognár Gabriella \\ egyetemi tanár, Miskolci Egyetem, Gép- és Terméktervezési Intézet \\ 3515 Miskolc, Miskolc-Egyetemváros, e-mail: v.bognar.gabriella@uni-miskolc.hu
}

\begin{abstract}
Absztrakt
A cikk célja, az EFOP Fiatalodó és Megújuló Egyetem - Innovativ Tudásváros - a Miskolci Egyetem intelligens szakosodást szolgáló intézményi fejlesztése projekt támogatásával elért eredmények bemutatása. A vizsgált mikrokapcsolók meghibásodási adatait, gyorsitott élettartam vizsgálati módszerrel kívánjuk elemezni. A tesztsorozatok eredményeinek elemzésekor meghatározzuk az ún. Weibull-eloszlás paramétereit és vizsgáljuk a tönkremeneteli és meghibásodási folyamatok hatását a mikrokapcsolók élettartamára vonatkozóan.
\end{abstract}

Kulcsszavak: mikrokapcsoló, Weibull - eloszlás, gyorsitott élettartam teszt

\begin{abstract}
The aim of this paper is to present the results achieved with the support of the EFOP Youth and Renewable University - Innovative City of Knowledge - the institutional development project of the University of Miskolc for intelligent specialization. The failure data of the tested micro switches are analyzed by accelerated life testing method. During the analysis of the test results the parameters of the Weibull distribution are determined, and we investigate the effect of the failure and malfunction processes on the life time of the micro switches.
\end{abstract}

Keywords: micro switches, Weibull - distribution, Accelerated Life Testing

\section{Bevezetés}

A mai gyártók nagy nyomást gyakorolnak a fejlesztőkre, hogy új termékeket dolgozzanak ki minél magasabb technológiai tartalommal rekordidő alatt, miközben növelik a termelékenységet, a termékek megbízhatóságát és azok minőségét. A vevők által megkövetelt színvonal motiválja a különféle módszerek kidolgozását, mint például a párhuzamos mérnöki fejlesztés, termék- és folyamatfejlesztési kísérlettervezési módszerek kialakítását. A nagyobb megbízhatóság követelményei növelték az anyagok, alkatrészek és rendszerek tesztelésének szükségességét. A nagy megbízhatóság eléréséhez szükséges a tervezési és gyártási folyamatok javítása $[1,3-5,8,15]$.

A gyorsított élettartam tesztekkel a gyártók törekszenek a termékek felhasználási arányának és az elöregedési sebességének valamint bizonyos típusú igénybevételek növelésére.

Olyan hasznos megbízhatósági információkhoz jutnak, melyek segítségével könnyedén elérhetjük a kívánt eredményt normál müködési idö alatt, évek helyett csupán néhány hónap alatt. Azonban ehhez 
mesterséges környezetet kell biztosítanunk a vizsgálatok számára, mint például a feszültség - áramterhelés, a rezgés és a hőmérsékelt nagyobb tartományban való emelésével. Igy a termékek valós használati időtartama jelentősen csökken, de megállapítható a valós élettartamuk. Kísérletekben specifikusan megválaszthatjuk, hogy egy vagy több kísérleti változó intenzitásának változtatásával tesszük-e ezt. Esetünkben, a hömérséklet és páratartalom szintjének növelésével kívánjuk felgyorsítani a tönkremeneteli mechanizmusok bekövetkezését [1,3-5,8,15].

A mikrokapcsolók a vezérléstechnika, az irányítástechnika és az automatizálás nagyon fontos elemei. Jellemzőjük a nagy mechanikai élettartam és emellett a viszonylag nagy elektromos teljesítmény kapcsolása. A kapcsolók a villamos áramkört üzem közben nyitó, valamint záró érintkezős készülékelemek, melyeket a hétköznapi életben is használunk háztartási gépekben, barkácsgépekben és jármüvekben egyaránt $[6,14]$.

Kutatásunk célja gyorsított élettartam tesztekkel olyan élettartam előrejelző módszert kialakítani, melynek segítségével a mérnöki szerkezeti elemek, mikrokapcsolók élettartamát, megbízhatóságát és az esetleges karbantartási időket gyakorlatban előre tudjuk jelezni. Számításba vesszük a termékek sajátos müködési feltételeit, körülményeit és meghibásodási folyamatait. A mikrokapcsolók több típusán is élettartam teszteket végzünk, több környezeti és müködési hatást figyelembe véve, úgymint kétféle páratartalom szint és kapcsolási idő. Ezen vizsgálatok alapján élettartam becslő modell kifejlesztését szeretnénk elérni.

\section{Weibull - eloszlás alkalmazása a mikrokapcsolók gyorsított élettartamának meghatá- rozása}

Waloddi Weibull (1887-1979) svéd mérnök az időfüggő meghibásodási gyakoriságot olyan eloszlással írta fel, amely teljes életfázisában használható az élettartam vizsgálatokra. A Weibull-eloszlás általános, háromparaméteres alakjával az eloszlásfüggvényt (1) a következőképpen írhatjuk fel [1,2,10,11,13,14]:

$$
F(t)=\left\{\begin{array}{l}
1-\exp \left[-\frac{(t-\gamma)^{\beta}}{\alpha}\right], \text {, ha } t \geq \gamma, \\
0, \\
\text { ha } t<\gamma .
\end{array}\right.
$$

Az $F(t)$ függvény megadja a $t$ tényleges müködési idő alatti meghibásodási valószínűséget. Az (1) öszszefüggésben a $t$ a statisztikus változó (az idő órákban vagy a müködtetések száma)

$\alpha>0$ a skalárparaméter,

$\beta>0$ az alakparaméter,

$\gamma \geq 0$ a helyparaméter.

Az $\eta$ a mértékparaméter, vagy karakterisztikus élettartam. Vezessük be az $\eta=\alpha^{1 / \beta}$ helyettesítést az (1) kifejezésbe. Így az előzőekben felírt eloszlásfüggvény alakja:

$$
F(t)=\left\{\begin{aligned}
1-\exp \left[-\left(\frac{t-\gamma}{\eta}\right)^{\beta}\right], & \text { ha } t \geq \gamma, \\
0, & \text { ha } t<\gamma .
\end{aligned}\right.
$$


A $\gamma$ helyparaméter a gyakorlati alkalmazásoknak csak kis részében egyenlő 0 -val, a mintavételi terveket mégis a $\gamma=0$ esetre adják meg. A $\beta$ alakparaméter értéke a sürüségfüggvény alakját határozza meg. A Weibull-eloszlás sủrüségfüggvénye $\gamma=0$ esetben a (2) képletből differenciálással határozható meg (lásd 1. ábra).

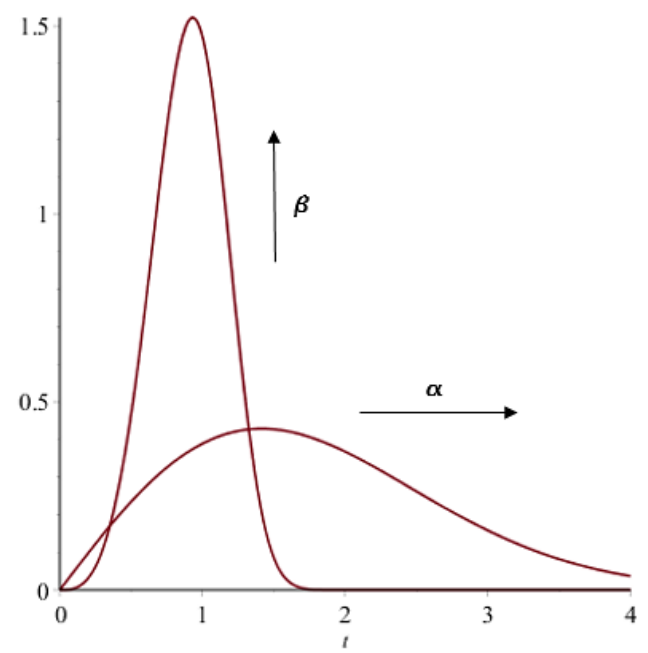

1. ábra $\alpha$ és $\beta$ hatása a Weibull-eloszlás sürüségfüggvény alakjára

$$
f(t)=F^{\prime}(t)=\left\{\begin{array}{cc}
\frac{\beta}{\eta}\left(\frac{t}{\eta}\right)^{\beta-1} & \exp \left[-\left(\frac{t}{\eta}\right)^{\beta}\right], \text { ha } t \geq 0 \\
0, & \text { ha } t<0 .
\end{array}\right.
$$

Ha $\beta<1$, akkor az $f(t)$ monoton csökkenő függvény, ez a korai meghibásodások szakaszát jelöli. Ha $\beta=1$, akkor az exponenciális eloszlást kapjuk, ez a véletlen meghibásodások szakasza.

Ha $\beta>1$, akkor a sủrüségfüggvénynek maximum helye van, ez az elhasználódással összefüggő meghibásodások szakaszára jellemző $[1,2,10,11,13,14]$.

\section{A vizsgált termékek leggyakoribb meghibásodása kapcsolók jellemzői, működése}

Mikrokapcsolókra nagy mechanikai élettartam és viszonylag nagy elektromos teljesítmény kapcsolása jellemző. A konstrukció alapvető követelménye, hogy a müködtetéshez szükséges kis erő és a kapcsolás létrehozásához meghatározott út az élettartam során csak minimális mértékben változhat meg, igen lassú müködtetés esetén is a kapcsolásnak pillanatszerủen kell megtörténnie. Ilyen eset például a hőtáguláson alapuló ikerfémes elemmel müködtetett elmozdulás. A kapcsolók a villamos áramkört üzem közben nyitó, valamint záró érintkezős készülékelemek. Használat során a kapcsolóknak nagyszámú megszakítás-zárás ciklust kell végezniük, ezért élettartamukat elsősorban az anyagvándorlás, az érintkezők kopása befolyásolja és határozza meg. Megbízhatóságuk nagymértékben megnövekedett, igazodva az aktív és passzív elemek hosszú élettartamához[6,8,9,12].

A mikrokapcsolók egyik leggyakoribb problémája a magas hőmérsékletből adódó deformáció. Ennek több oka is lehet, egyrészt elektromos túlterhelésből adódó, másrészt a kapcsolók megengedettnél 
magasabb számú kapcsolgatásából bekövetkező túlmelegedés. Az áramkör zárása és megszakítása közben elektromos ív jön létre, ennek következménye, az anyagvándorlás, a hőképződés és az átmeneti ellenállás megnövekedése, így a kapcsolóval érintkező alkatrészek átmelegedhetnek, valamint a kapcsolóban lévő előfeszített alkatrészek, (például rugó) túlmelegedés következtében kilágyulhatnak.

Másik jellemző meghibásodási probléma a mikrokapcsoló kapcsológombjának a kopása, amely adódhat rossz konstrukciós kialakításból, a nem megfelelő anyagválasztásból, gyártási hibákból, de a müködtetés közbeni oldalirányú nyomóterhelésböl és a magas kapcsolási számtól is. Mindezen hibaokok közös következményeképpen az alkatrész megkophat és eltörhet (lásd 2.ábra).

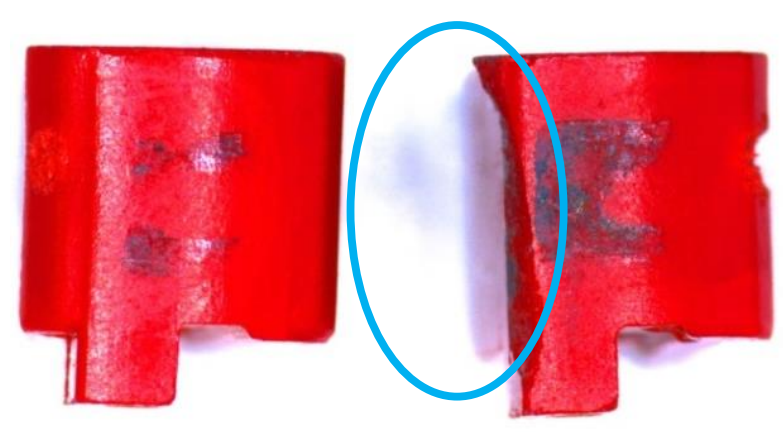

2.ábra Mikrokapcsoló kapcsoló gombjának kopása

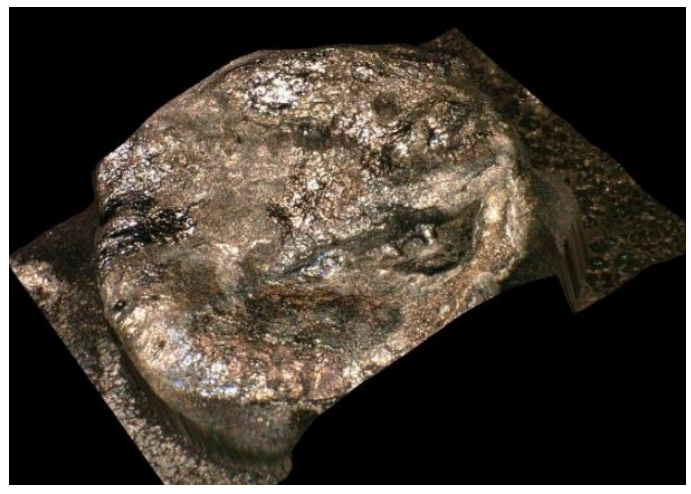

3.ábra A mikrokapcsoló érintkezö felületének beégése (valóságban az érintkezö felület átméröje $4 \mathrm{~mm}$ )

A 3. ábrán a mikrokapcsolók érintkező felületének beégése látható. A meghibásodást több tényező is befolyásolhatja, mint például a páratartalom, az érintkezési idő, az áram neme, a gép nagyobb mértékü rezgése valamint a felületek nagysága, anyaga és szennyezettsége is. Ha ezek a feltételek nem megfelelőek szétkapcsolás során nagy lesz az ív, az átmeneti ellenállás megnövekszik. Ezek okán pedig az érintkezők felületén hőmérséklet növekedést követően nagymértékü égési foltok keletkeznek, valamint a felület teljes kormolódása is bekövetkezhet. A kontaktálló felületek hiába érintkeznek egymással, elvesztik megfelelö vezetöképességüket.

További meghibásodási probléma, amikor a kapcsolón az elöírtnál nagyobb áram folyik, illetve zárlat esetén a konstrukció szétég, a kapcsolóban lévő laprugó deformálódik, elveszítheti rugalmasságát és ezzel eredeti funkciója megszünik; ezért a gépet nem lehet ki- vagy bekapcsolni [10-14].

\section{Berendezés bemutatása és mérések leírása}

A 4. ábrán látható a mikrokapcsoló tesztelő berendezés amelyen, a termékeket különálló egységként teszteljük. Az erre a célra megtervezett és legyártott munkalapon egyszerre négy darabot tudunk vizsgálni azonos körülmények között, melyeket egy pneumatikus munkahenger és egy nyomólap segítségével müködtetünk. A vizsgálatokhoz készített PLC program segítségével megadhatjuk és nyomon követhetjük a pneumatika által müködtetett kapcsolásokat és a mikrokapcsolókon ténylegesen végbemenő kapcsolások számát. A vizsgálat tárgya, hogy hány kapcsolás után mennek tönkre a termékek. Egy kapcsoló hibásnak minősíthető, ha a kapcsolási funkciót már nem képes ellátni. 
Több teszt lefuttatását követően is azt tapasztaltuk, hogy hozzávetőlegesen 130.000 kapcsolást még hibamentesen tudnak teljesíteni a vizsgált kapcsolók, meghaladva azt már nagy eséllyel meghibásodhatnak. Jelentkeznek a már korábban ismertetett tönkremeneteli formák (lásd 3. ábra). Az eddig vizsgálatok alapján a leggyakrabban az érintkező felületek beégését tapasztaltuk. Általában egy bizonyos kapcsolási ciklusszám felett az érintkezők felületén egyre több szennyeződés és égési folt jelenik meg, magasabb kapcsolási ciklusszám felett pedig a kapcsoló mechanika is roncsolódásokat szenvedhet.

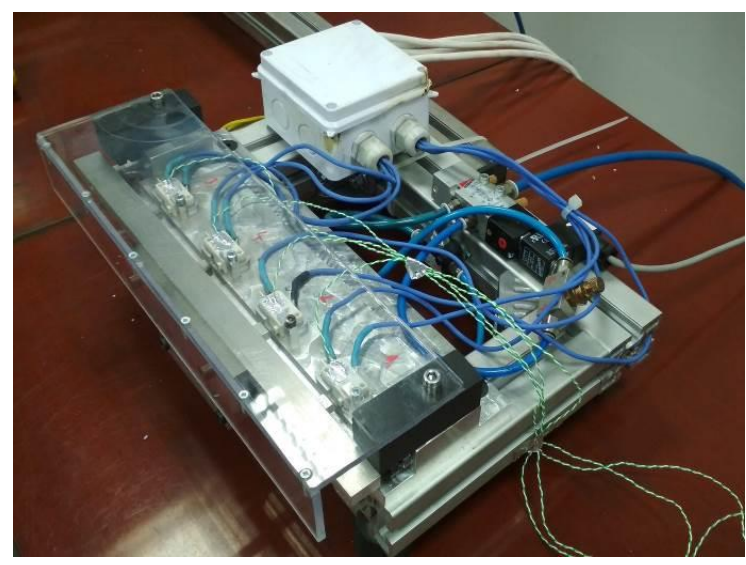

4. ábra. A mikrokapcsolókat vizsgáló berendezés

A 5. ábrán bemutatott diagramon a mikrokapcsolók utolsó 5000 kapcsolásánál, a hőmérsékletmérő müszer által rögzített értékek láthatók. Az adatgyüjtő 10 másodpercenként rögzíti a teszt közbeni értékeket, és ez egy látványos hőmérséklet diagramon jelenik meg. A diagramról leolvasható, hogy viszonylag nagy múködési különbségek jelentkeznek egyes kapcsolóknál.

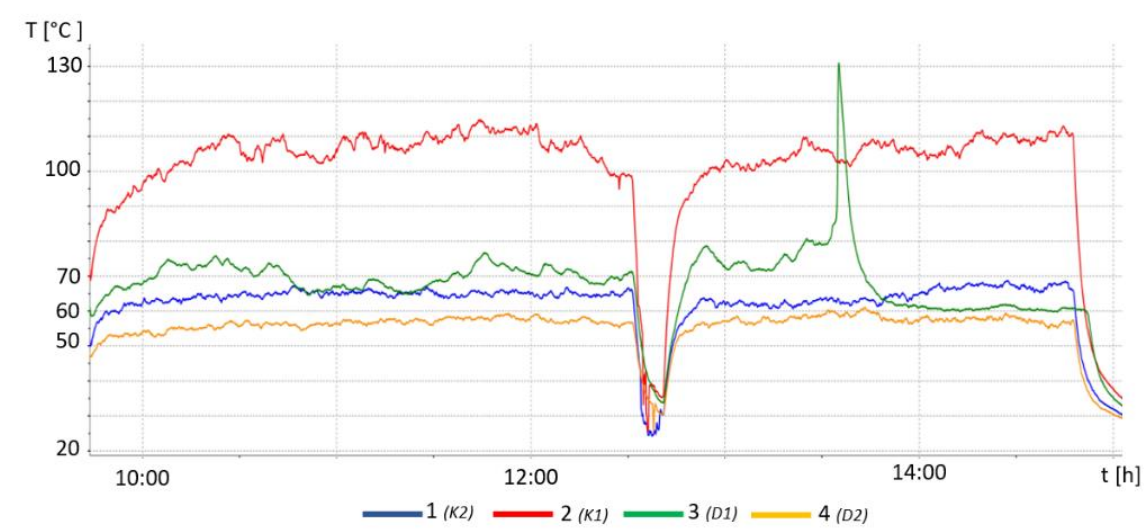

5. ábra. Az utolsó 5000 kapcsolási ciklusánál rögzitett hömérséklet, 0,3s kapcsolási idő (0,3s bekapcsolás, $0,3 \mathrm{~s}$ kikapcsolás) és $60 \%$ páratartalom mellett

A 5. ábrán látható diagram vízszintes tengelye a tesztek eltelt idejét jelöli, a függőleges tengely pedig a hőmérsékletet. A zöld színnel jelölt görbe azt mutatja, hogy a hármas helyen lévő mikrokapcsoló mintájának a hőmérséklete hirtelen megugrik $131^{\circ} \mathrm{C}$-ra, ekkor következik be a tönkremenetel. A diagramról 
leolvasható, hogy nem az a kapcsoló ment tönkre a leghamarabb, amelyik a teszt korábbi szakaszaiban a legmagasabb melegedést mutatta, hanem amelyik viszonylag átlagosan viselkedett $[16,17]$.

\section{Összefoglalás}

A cikkben ismertettük a projekt által támogatott publikációk eredményeit, melyek kiterjedtek a szakirodalomkutatásra, a témához szorosan kapcsolódó szakmai háttér tanulmányozására, a gyorsított élettartam módszerének és a Weibull eloszlás matematikai hátterének megismerésére. Továbbá összefoglaltuk a mikrokapcsolók leggyakrabban előforduló meghibásodási formáit és bemutattuk a termékek tesztelésére alkalmas berendezést, melyen folyamatosan zajlanak a mérések különbözö páratartalom illetve kapcsolási idő beállításokkal. A vizsgálatokat követően élettartam becslő modell kifejlesztését szeretnénk megvalósítani a termékek élettartamára és megbízhatóságára vonatkozóan.

\section{Köszönetnyilvánítás}

A cikkben összefoglalt kutató munka az EFOP-3.6.1-16-2016-00011 jelü „Fiatalodó és Megújuló Egyetem - Innovatív Tudásváros - a Miskolci Egyetem intelligens szakosodást szolgáló intézményi fejlesztése" projekt részeként - a Széchenyi 2020 keretében - az Európai Unió támogatásával, az Európai Szociális Alap társfinanszírozásával valósul meg.

\section{Irodalom}

[1] Balogh, A., Dukáti, F., Sallay, L.: Minöség-ellenőrzés és megbizhatóság, Müszaki Könyvkiadó, Bp.,1980, ISBN 0-262-04219-3

[2] Meeker, W. Q., Escobar, L. A.: Statistical Methods for Reliability Data, Wiley-Interscience Publication - John Wiley\& Sons, INC, Copyright,1998, ISBN 978-0-471-14328

[3] Reliability in electronic, Technical article, The expert in power 1-11, www.xppower.com, 2018.10.15

[4] Hartzel, A.L. et al., MEMS Reliability, MEMS Reference Shelf, Lifetime Prediction, Springer Science + Business Media, LLC 2011, 9-42. https://doi.org/10.1007/978-1-4419-6018-4_2

[5] European Power Supply Manufacturers Association, Guidelines to Understanding Reliability Prediction Edition 24 June 2005, (www.epsma.org)

[6] Jánoki, I., Pn2 és Pm2 típusú mikrokapcsolók végminősitő eljárása, 1984, Műszaki Doktori Értekezés, Budapesti Müszaki Egyetem, Gépészmérnöki Kar

[7] Gregász, T., Nemfémes szerkezeti anyagok élettartam problémáinak minöségügyi megközelitése, NYME. Sopron, PhD értekezés, 2009.

[8] Mojzes, I., Mikroelektronika és technológia, Müegyetemi Kiadó, Budapest, 2005., ISBN 963420 8479

[9] Lautner, P., Mikrokapcsolók, Híradástechnika Vol. XXXIV No 5., 1983, pp. 237-239

[10] Sipkás, V., Vadászné Bognár, G., Mikrokapcsolók gyorsitott élettartam vizsgálata, Jelenkori Társadalmi és Gazdasági Folyamatok 12 (4), 95-102. https://doi.org/10.14232/jtgf.2017.4.95-102

[11] Sipkás V., Vadászné Bognár, G., Mikrokapcsolók élettartamának vizsgálata, Jelenkori Társadalmi és Gazdasági Folyamatok Vol. XII. No. 2017/4, pp. 92-102, ISSN 1788-7593 https://doi.org/10.14232/jtgf.2017.4.95-102 
[12] Sipkás, V., Vadászné Bognár, G., Mikrokapcsolók Weibull-eloszlásán alapuló gyorsitott élettartam vizsgálatok, Doktoranduszok Fóruma, Miskolci Egyetem, Gépészmérnöki és Informatikai kar Szekciókiadványa, 2017, pp. 105-109, ISBN 978-963-358-166-7

[13] Sipkás, V., Vadászné Bognár, G.: The Application of Accelerated Life Testing Method for Micro Switches, International Journal of Instrumentation and Measurement, http://www.iaras/journals/ijim,Vol. 3, 2018, pp. 1-5. ISSN 2534-8841

[14] Sipkás, V., Vadászné Bognár, G.: Gyorsitott élettartam vizsgálat alkalmazása mikrokapcsolókra, Erdélyi Magyar Müszaki Tudományos Társaság (EMT) Gépészeti Szakosztálya által szervezett XXVI. Nemzetközi Gépészeti Konferencia kiadványa, 2018, pp. 405-408, ISSN 2068-1267

[15] Sipkás, V., Vadászné Bognár, G., Mikrokapcsolók meghibásodási analizise, Doktoranduszok Fóruma, Miskolci Egyetem, Gépészmérnöki és Informatikai Kar kiadványa, 2019. pp.91-95.,

[16] Sipkás, V., Vadászné Bognár, G.: Kerti gépekben alkalmazott mikrokapcsolók élettartam adatainak vizsgálata, Multidiszciplináris Tudományok, Vol. 9, No.2, 2019, pp. 90-95, https://doi.org/10.35925/j.multi.2019.2.13

[17] Sipkás, V., Vadászné Bognár, G.: Testing accelerated life data of micro switches, Design of Machines and Structures, Vol. 9, No.2, 2019, pp. 44-50, ISSN 1785-6892 